\title{
Cleft sidedness and congenitally missing teeth in patients with cleft lip and palate patients
}

\author{
Abdolreza Jamilian ${ }^{1 *}$, Alessandra Lucchese ${ }^{2}$, Alireza Darnahal ${ }^{3}$, Zinat Kamali $^{4}$ and Letizia Perillo ${ }^{5}$
}

\begin{abstract}
Background: The aim of this study was to investigate the prevalence of cleft sidedness, and the number of congenitally missing teeth in regard to cleft type and gender.

Methods: The charts, models, radiographs, and intraoral photographs of 201 cleft patients including 131 males with the mean age of $12.3 \pm 4$ years and 70 females with the mean age of $12.6 \pm 3.9$ years were used for the study. $T$ test, Chi-square, and binomial tests were used for assessment of the data.

Results and conclusions: One hundred forty-eight of the subjects suffered from cleft lip and palate followed by 41 subjects who suffered from cleft lip and alveolus. Chi-square test did not show any significant difference between the genders. Binomial test showed that left-sided cleft was more predominant in unilateral cleft lip and palate patients $(P<0.001)$. This study also showed that the upper lateral incisors were the most commonly missing teeth in the cleft area.
\end{abstract}

Keywords: Cleft lip and palate, Cleft sidedness, Missing teeth, Cleft lip and alveolus

\section{Background}

Cleft lip and/or palate (CLP) is among the most common congenital human malformations. Failure of fusion of the maxillary and medial nasal prominences or between the palatal processes results in clefts of varying extent, unilaterally or bilaterally. CLP affects between one and seven out of 1000 newborns $[1,2]$. The frequency of cleft is higher in Asian people than in other races $[3,4]$.

Tooth agenesis, also known as hypodontia or congenital absence of teeth, is the most frequently observed developmental anomaly of the human dentition. The prevalence of congenitally missing teeth in the general population has been reported within a range of 0.027 to $10.1 \%$, which varies greatly according to geographic location and race [5-7]. Clefts of all types are often associated with congenitally missing teeth,[8] and when compared with the general population, subjects with

\footnotetext{
* Correspondence: info@jamilian.net

1Department of Orthodontics, Orthognathic Surgery, Tehran Dental Branch, Craniomaxillofacial Research Center, Islamic Azad University, No 2713, Vali Asr St, Tehran 1966843133, Iran

Full list of author information is available at the end of the article
}

CLP have always been found to have a higher prevalence of dental anomalies, such as variations in tooth number and position, and reduced tooth dimensions, most of which are localized in the area of the cleft defect [9-11]. Rullo et al. examined the prevalence of different types of dental anomalies in children with cleft and found that congenital absence of the cleft-side lateral incisor was observed in $40 \%$ of the samples and a total of $30 \%$ patients showed supernumerary teeth at the incisors region [12].

Baek and Kim [5] investigated the differences in the congenital missing teeth pattern in terms of tooth type and cleft sidedness in Korean CLP patients and found that boys had more congenital missing maxillary lateral incisors on the cleft side than girls, but on the non-cleft side, the congenital absence of the maxillary second premolar was more frequent in girls.

To date, few researches have individually studied the different types of cleft including unilateral or bilateral cleft lip, cleft palate, cleft lip and palate, and cleft alveolus and the incidence of tooth agenesis in each type. Therefore, the aim of this study was to investigate the 
prevalence of different cleft types, cleft sidedness, and congenitally missing teeth in each cleft type.

\section{Methods}

The study conducted as a follow-up of the study done by Jamilian et al. [13] was carried out in accordance with the ethical standards set forth in the 1964 Declaration of Helsinki. Informed written consent was obtained from each patient and a parent or guardian. Two hundred two consecutive cleft lip and/or palate patients who were referred to orthodontic department of SBUMS from 2009 until 2011 were included in the study. Except for one subject who was excluded from the study, none of the subjects had other known syndromes. Subjects' distribution according to gender can be seen in Table 1. The final sample of 201 subjects included 131 males with the mean age of $12.3 \pm 4$ years and 70 females with the mean age of $12.6 \pm 3.9$ years. The patients' population was racially and ethnically similar. Lateral cephalograms, OPGs, and photos of patients which were taken for treatment were used for observational purposes of this study. Panoramic and/or periapical and occlusal radiographs of the patients were used to determine the presence or absence of the teeth.

Two observers analyzed the records of the patients at the same time. The results of their observations were blinded to each other. No differences were found between the assessments.

The Statistical Package for Social Sciences, Version 20 (SPSS Inc. Chicago, IL, USA) was used to analyze the data. $T$ test, Chi-square, and binomial tests were used to analyze the data and $P$ value was set at $P<0.05$.

\section{Results}

Two hundred one consecutive cleft patients including 131 males and 70 females were examined and classified according to their cleft type. Observation of the records showed that the majority of patients suffered from cleft lip and palate (148 subjects), while only three of the subjects suffered just from cleft lip. Further distribution of the subjects according to the type of cleft can be seen in Table 2. Cleft lip patients were not included in the statistical analysis due to the very low number of patients. Although there was a higher tendency for male dominance in the unilateral cleft lip and alveolus and unilateral cleft lip and palate patients, Chi-square test showed that there was no relationship between patients' sex and the

Table 1 Gender distribution of samples

\begin{tabular}{lll}
\hline Gender & $N(\%)$ & $\begin{array}{l}\text { Age (year) } \\
\text { Mean } \pm \text { SD }\end{array}$ \\
\hline Male & $131(65.2)$ & $12.3 \pm 4$ \\
Female & $70(34.8)$ & $12.6 \pm 3.9$ \\
\hline
\end{tabular}

affected side (Table 3) In addition, binomial test showed that the patients suffering from unilateral cleft lip and palate had higher incidence on the left side $(P<0.001)$ (Table 4). As can be seen in Table 5, the incidence of missing teeth in cleft side is higher than the non-cleft side of both unilateral cleft lip and alveolus and unilateral cleft lip and palate subjects.

\section{Discussion}

This study showed that unilateral and bilateral cleft lip and palate followed by unilateral cleft lip and alveolus were more common than other types of cleft in Persian population. Moreover, the incidence of cleft was significantly higher on the left side of unilateral cleft lip and palate patients. The findings of this study are similar to studies of other races. Fraser [14] reported the prevalence of left-sided clefts to be $66.6 \%$, and Wilson [15] reported it as $60 \%$. Kim and Baek [3] also found that patients had a significantly higher incidence on the left side than on the right. Their results showed that the prevalence of left-sided clefts in the unilateral cleft lip and palate patients was $67.4 \%$. While they did not find any significant difference in the distribution of cleft sidedness in unilateral cleft lip and alveolus patients.

Similar to the results of our study, hypodontia was found to occur more frequently on the cleft side than on the unaffected side [16]. Shapira et al. [17] also found that hypodontia of both the maxillary lateral incisors and second premolars were more frequent on the left side, which also had a higher frequency of clefting. In current study, substantially more missing teeth were detected in non-cleft side of unilateral cleft lip and alveolus patients. Similarly, Baek [5] and Kim also found considerably lower prevalence of hypodontia in the non-cleft side of these patients.

Ranta [18] reported that the upper lateral incisors are the most commonly missing teeth in the cleft area, followed by the second premolars in cleft lip and palate patients. These findings are similar to the findings of the current study for cleft lip and palate and cleft lip and alveolus patients. This finding has been explained by the proximity of the cleft to the lateral incisor region, which may strike and divide the primordial tissue related to the developing lateral incisor field [16].

One of the limitations of the current study which affects generalizing the results is the small number of patients. Further multi-center studies with a larger sample size and different races would definitely improve the literature. Future multidisciplinary studies focusing on genetic aspects of cleft patients in order to justify the higher prevalence of left-sided cleft are required. 
Table 2 Distribution of samples according to cleft type

\begin{tabular}{|c|c|c|c|c|c|c|c|c|}
\hline Gender & Unilateral cleft lip & Bilateral cleft lip & $\begin{array}{l}\text { Unilateral cleft } \\
\text { lip and alveolus }\end{array}$ & $\begin{array}{l}\text { Bilateral cleft } \\
\text { lip and alveolus }\end{array}$ & Cleft palate & $\begin{array}{l}\text { Unilateral cleft } \\
\text { lip and palate }\end{array}$ & $\begin{array}{l}\text { Bilateral cleft } \\
\text { lip and palate }\end{array}$ & Total \\
\hline Male & 1 & 1 & 18 & 8 & 2 & 64 & 37 & 131 \\
\hline Female & - & 1 & 11 & 4 & 7 & 27 & 20 & 70 \\
\hline Total & 1 & 2 & 29 & 12 & 9 & 91 & 57 & 201 \\
\hline
\end{tabular}

Table 3 Distribution of samples according to gender and relationship between gender and affected side

\begin{tabular}{|c|c|c|c|c|c|c|}
\hline \multirow{2}{*}{$\begin{array}{l}\text { Cleft side } \\
\text { Gender }\end{array}$} & \multicolumn{2}{|c|}{ Unilateral cleft lip } & \multicolumn{2}{|c|}{ Unilateral cleft lip and alveolus } & \multicolumn{2}{|c|}{ Unilateral cleft lip and palate } \\
\hline & Male & Female & Male & Female & Male & Female \\
\hline Right & 1 & 0 & 8 & 3 & 15 & 8 \\
\hline Left & - & - & 10 & 8 & 49 & 19 \\
\hline Total & 1 & 0 & 18 & 11 & 64 & 27 \\
\hline$P$ value & - & & 0.355 & & 0.535 & \\
\hline
\end{tabular}

Table 4 Distribution of samples according to cleft side

\begin{tabular}{|c|c|c|c|c|c|c|}
\hline \multirow{2}{*}{$\begin{array}{l}\text { Cleft } \\
\text { side }\end{array}$} & \multicolumn{2}{|c|}{ Unilateral cleft lip } & \multicolumn{2}{|c|}{ Unilateral cleft lip and alveolus } & \multicolumn{2}{|c|}{ Unilateral cleft lip and palate } \\
\hline & Right & Left & Right & Left & Right & Left \\
\hline Total & 1 & - & 11 & 18 & 23 & 68 \\
\hline$P$ value & - & & 0.264 & & 0.001 & \\
\hline
\end{tabular}

Table 5 Number of missing teeth in unilateral cleft lip and alveolus and unilateral cleft lip and palate subjects

\begin{tabular}{|c|c|c|c|c|}
\hline & \multicolumn{2}{|c|}{ Unilateral cleft lip and alveolus } & \multicolumn{2}{|c|}{ Unilateral cleft lip and palate } \\
\hline & Cleft side & Non-cleft side & Cleft side & Non-cleft side \\
\hline Upper right central incisor & - & - & - & - \\
\hline Upper left central incisor & - & - & - & - \\
\hline Upper right lateral incisor & 5 & - & 16 & 9 \\
\hline Upper left lateral incisor & 9 & - & 39 & 2 \\
\hline Upper right 2nd premolar & 1 & - & 1 & 4 \\
\hline Upper left 2nd premolar & - & - & 3 & 2 \\
\hline Lower right central incisor & - & - & 2 & 1 \\
\hline Lower left central incisor & - & - & 1 & 2 \\
\hline Lower right lateral incisor & - & - & 1 & 1 \\
\hline Lower left lateral incisor & - & - & 1 & 1 \\
\hline Lower right 2nd premolar & - & - & - & 2 \\
\hline Lower left 2nd premolar & - & - & - & 3 \\
\hline Total & 15 & 0 & 64 & 27 \\
\hline
\end{tabular}




\section{Conclusions}

Current study showed that most cleft patients suffered from cleft lip and palate followed by unilateral cleft and alveolus. In this study, no differences were found in regard to the gender of the patients. The left side of the patients was affected substantially more than the right side. The frequency of the missing upper lateral incisors in the cleft side of the patients was significantly higher than the non-cleft side.

\section{Competing interests}

The authors declare that they have no competing interests.

\section{Authors' contributions}

AJ was responsible for study design, administration, recruitment and treatment, drafting, writing and revising the report, critical revision and fina approval of the article. LP and AL were responsible for the study concept, data interpretation, critical revision, drafting and final approval of the article. AD was responsible for sample selection, recruitment of participants, data collection and obtaining ethical approval. ZK was responsible for statistical analysis and data interpretation of the article. All authors read and approved the final manuscript.

\section{Author details}

${ }^{1}$ Department of Orthodontics, Orthognathic Surgery, Tehran Dental Branch, Craniomaxillofacial Research Center, Islamic Azad University, No 2713, Vali Asr St, Tehran 1966843133, Iran. ${ }^{2}$ Department of Orthodontics, Vita-Salute San Raffaele University, Milan, Italy. ${ }^{3}$ Department of Orthodontics, Dental Branch, Islamic Azad University, Tehran, Iran. ${ }^{4}$ National Nutrition and Food Technology Research Institute, Faculty of Nutrition Sciences and Food Technology, Shahid Beheshti University of Medical Sciences, Tehran, Iran. ${ }^{5}$ Orthodontic Unit and Chair of Postgraduate Orthodontic Program, Multidisciplinary Department of Medical-Surgical and Dental Specialties, Second University of Naples, Naples, Italy.

Received: 22 November 2015 Accepted: 31 March 2016

Published online: 09 May 2016

\section{References}

1. Altalibi M, Saltaji H, Edwards R, Major PW, Flores-Mir C. Indices to assess malocclusions in patients with cleft lip and palate. Eur J Orthod. 2013;35(6): 772-82.

2. Rullo R, Di Maggio D, Addabbo F, Rullo F, Festa VM, Perillo L. Speech outcome in unilateral complete cleft lip and palate patients: a descriptive study. Eur J Paediatr Dent. 2014;15(3):293-6.

3. Kim NY, Baek SH. Cleft sidedness and congenitally missing or malformed permanent maxillary lateral incisors in Korean patients with unilateral cleft lip and alveolus or unilateral cleft lip and palate. Am J Orthod Dentofacial Orthop. 2006;130(6):752-8

4. Jamilian A, Nayeri F, Babayan A. Incidence of cleft lip and palate in Tehran. J Indian Soc Pedod Prev Dent. 2007;25(4):174-6.

5. Baek SH, Kim NY. Congenital missing permanent teeth in Korean unilateral cleft lip and alveolus and unilateral cleft lip and palate patients. Angle Orthod. 2007;77(1):88-93.

6. Symons AL, Stritzel F, Stamation J. Anomalies associated with hypodontia of the permanent lateral incisor and second premolar. J Clin Pediatr Dent. 1993;17(2):109-11.

7. Jamilian A, Perillo $L$, Rosa M. Missing upper incisors: a retrospective study of orthodontic space closure versus implant. Prog Orthod. 2015;16:2.

8. Larson M, Hellquist $R$, Jakobsson OP. Dental abnormalities and ectopic eruption in patients with isolated cleft palate. Scand J Plast Reconstr Surg Hand Surg. 1998;32(2):203-12.

9. Lourenco Ribeiro L, Teixeira Das Neves L, Costa B, Ribeiro Gomide M. Dental anomalies of the permanent lateral incisors and prevalence of hypodontia outside the cleft area in complete unilateral cleft lip and palate. Cleft Palate Craniofac J. 2003;40(2):172-5.

10. Jamilian A, Showkatbakhsh R, Darnahal A, Baniasad N, Kamali Z. Prevalence of dental anomalies in children with different types of cleft. Dent Med Probl. 2015;52(2):192-6.
11. dos Santos PBD, Garib DG, Janson G, Assis VH. Association between tooth size and interarch relationships in children with operated complete unilateral cleft lip and palate. Prog Orthod. 2015;16:13.

12. Rullo R, Festa VM, Rullo R, Addabbo F, Chiodini P, Vitale M, et al. Prevalence of dental anomalies in children with cleft lip and unilateral and bilateral cleft lip and palate. Eur J Paediatr Dent. 2015;16(3):229-32.

13. Jamilian A, Jamilian M, Darnahal A, Hamedi R, Mollaei M, Toopchi S. Hypodontia and supernumerary and impacted teeth in children with various types of clefts. Am J Orthod Dentofacial Orthop. 2015;147(2):221-5.

14. Fraser FC. The genetics of cleft lip and cleft palate. Am J Hum Genet. 1970; 22(3):336-52

15. Wilson ME. A ten-year survey of cleft lip and cleft palate in the South West Region. Br J Plast Surg. 1972;25(3):224-8.

16. Shapira Y, Lubit E, Kuftinec MM. Congenitally missing second premolars in cleft lip and cleft palate children. Am J Orthod Dentofacial Orthop. 1999; 115(4):396-400.

17. Shapira Y, Lubit E, Kuftinec MM. Hypodontia in children with various types of clefts. Angle Orthod. 2000;70(1):16-21.

18. Ranta R. Hypodontia and delayed development of the second premolars in cleft palate children. Eur J Orthod. 1983;5(2):145-8.

\section{Submit your manuscript to a SpringerOpen ${ }^{\circ}$ journal and benefit from:}

- Convenient online submission

- Rigorous peer review

- Immediate publication on acceptance

- Open access: articles freely available online

- High visibility within the field

- Retaining the copyright to your article

Submit your next manuscript at springeropen.com 